\title{
ALPHA CHROMIUM FORMATION IN ALLOY 718 AND ITS EFFECT ON CREEP CRACK PROPAGATION
}

\author{
Xishan Xie, Gailian Wang, Jianxin Dong and Cuiwei Wu \\ University of Science and Technology Beijing, Beijing 100083,China \\ John Radavich \\ Micro-Met Laboratories, Inc., West Lafayette, IN47906, USA \\ Gangshu Shen \\ Ladish Co., Inc., Cudahy, WI53110-8902,USA \\ Bruce A. Lindsley \\ Special Metals Corporation, New Hartford, NY 13413,USA
}

\begin{abstract}
Structure stability study on Alloy 718 disks with four different forging/heat treatment process combinations, i.e. Standard718, Super I 718, Super II 718 and DA718, has been conducted with long time thermal exposure at $593^{\circ} \mathrm{C}\left(1100^{\circ} \mathrm{F}\right), 649^{\circ} \mathrm{C}\left(1200^{\circ} \mathrm{F}\right)$ and $677^{\circ} \mathrm{C}\left(1250^{\circ} \mathrm{F}\right)$ till $2000 \mathrm{hrs}$. A b.c.c chromium enriched phase $\alpha-\mathrm{Cr}$ has been identified by XRD,SEM,TEM and SAD methods. The existence of $\alpha-\mathrm{Cr}$ in Alloy 718 is also confirmed by Thermo-Calc method. The weight fraction of $\alpha-\mathrm{Cr}$ has been determined by special designed electrolytic isolation and micro-chemical analyses. $\alpha-\mathrm{Cr}$ precipitates are often in small globular particles $(\sim 0.3 \mu \mathrm{m})$ and form at the vicinity of $\delta-\mathrm{Ni}_{3} \mathrm{Nb}$ phase. More $\alpha-\mathrm{Cr}$ particles will precipitate in Alloy 718 at higher exposure temperatures and longer times. Retained stress can promote $\alpha-\mathrm{Cr}$ precipitation. The fractions of $\alpha-\mathrm{Cr}$ in 4 different processed Alloy 718 disks are not very high, only less than $1 \%$ wt. The highest fraction of $\alpha-\mathrm{Cr}$ in DA718 after $677^{\circ} \mathrm{C} / 2000 \mathrm{hrs}$ is about $0.62 \%$ wt and the $\alpha-\mathrm{Cr}$ fraction in Standard 718 after $677^{\circ} \mathrm{C} / 2000 \mathrm{hrs}$ is only $0.19 \%$ wt. Small amount of $\alpha-\mathrm{Cr}$ in Alloy 718 does not has serious deleterious effect on $650^{\circ} \mathrm{C}$ creep crack propagation rate. However, the impact energy does decrease with the thermal exposure times at $649^{\circ} \mathrm{C}$ and $677^{\circ} \mathrm{C}$.
\end{abstract}

Superalloys 718.625.706 and Various Derivatives

Edited by E.A. Loria

TMS (The Minerals. Metals \& Materials Society). 2001 


\section{Introduction}

Our previous studies on structure stability ${ }^{[1]}$ and the effect of processing on stability of Alloy $718^{[2]}$ show that when Alloy 718 was exposed for long time at temperature of $593^{\circ} \mathrm{C}, 649^{\circ} \mathrm{C}$ and $677^{\circ} \mathrm{C}, \alpha-\mathrm{Cr}$ can precipitate from $\gamma$-matrix in addition to $\delta-\mathrm{Ni}_{3} \mathrm{Nb}$ phase. $\alpha-\mathrm{Cr}$ formation is not only dependent on chemical composition, especially chromium content in Alloy $718^{|3|}$, but also dependent on residual strain produced by cold work ${ }^{[1]}$.

Superalloy producers and engine manufacturers are very interested in $\alpha$-Cr behavior and its effect on mechanical properties, especially on high temperature creep crack propagation rate, which is critical for disk application in aircraft and land-base gas turbines.

A research project has been undertaken to study the stability of 4 different processed Alloy 718 disks at $593^{\circ} \mathrm{C}-677^{\circ} \mathrm{C}$ thermal aging till $2000 \mathrm{hrs}$. This is a continuing investigation followed our previous work ${ }^{[2]}$ and the purpose of this paper concentrates on understanding the formation of $\alpha-\mathrm{Cr}$ and its effect on mechanical properties as follows:

1. $\alpha-\mathrm{Cr}$ behavior study including $\alpha-\mathrm{Cr}$ identification by XRD, SEM, TEM and SAD method, its morphology, size, distribution and precipitation behavior. The quantitative determination of $\alpha-\mathrm{Cr}$ in four different processed Alloy 718 disks with long time thermal aging has been conducted.

2. The effect of long time aging on $\alpha-\mathrm{Cr}$ formation and on mechanical properties, especially on $650^{\circ} \mathrm{C}$ creep crack propagation rate has been studied in detail.

\section{Experimental Procedures}

\section{Processes and Thermal Exposure}

Triple melt (VIM+ESR+VAR) Alloy 718 with the chemical composition as shown in Tab. 1, was forged into a simple turbine disk configuration $(230 \mathrm{~mm}$ in diameter) using 4 different forging/heat treatment process combinations as shown in Tab. 2. These disks were then cut into sections for thermal exposure at $593^{\circ} \mathrm{C}, 650^{\circ} \mathrm{C}$ and $677^{\circ} \mathrm{C}$ till $2000 \mathrm{hrs}$. The disks and samples ID are shown in Tab. 3.

Table 1. Chemical Composition of Investigated 718 Alloy(wt.\%)

\begin{tabular}{|c|c|c|c|c|c|c|c|c|c|c|c|}
\hline $\mathrm{C}$ & $\mathrm{Mn}$ & $\mathrm{Si}$ & $\mathrm{S}$ & $\mathrm{Cr}$ & $\mathrm{Ni}$ & $\mathrm{Mo}$ & $\mathrm{Nb}$ & $\mathrm{Ti}$ & $\mathrm{Al}$ & $\mathrm{B}$ & $\mathrm{Fe}$ \\
\hline 0.021 & 0.08 & 0.07 & 0.0003 & 17.89 & 53.88 & 2.99 & 5.36 & 0.94 & 0.49 & 0.0029 & bal \\
\hline
\end{tabular}

\section{Mechanical Tests}

Hardness, Charpy impact, $650^{\circ} \mathrm{C}$ tensile and notched stress rupture tests (notch factor $\mathrm{k}_{\mathrm{t}}=3.6$ ) were ran on all conditions as listed in Tab.3. $650^{\circ} \mathrm{C}$ creep crack propagation rate determination tests were ran by using compact tension specimens. 
Table 2. Alloy 718 Disks Processed in Four Different Conditions

\begin{tabular}{|l|l|l|l|}
\hline $\begin{array}{l}\text { Disk } \\
\text { No. }\end{array}$ & Classification & \multicolumn{1}{|c|}{ Processes } & Grain Size \\
\hline 1,2 & DA718 & Fine grain forging with direct age heat treatment & ASTM 11-12 \\
\hline 3,4 & Super I 718 & Fine grain forging with solution+age heat treatment & ASTM 11-12 \\
\hline 5,6 & Super II 718 & Ladish proprietary process(special fine grain forging+DA) & ASTM10-11 \\
\hline 7,8 & Standard 718 & Medium grain forging with solution +age heat treatment & ASTM7-9 \\
\hline
\end{tabular}

Table 3. Thermal Exposure Tests for Four Different Processed 718 Disks

\begin{tabular}{|c|c|c|c|c|}
\hline & $0 \mathrm{hr}$ & $500 \mathrm{hrs}$ & $1000 \mathrm{hrs}$ & $2000 \mathrm{hrs}$ \\
\hline $593^{\circ} \mathrm{C}\left(1100^{\circ} \mathrm{F}\right)$ & \multirow{3}{*}{ Disk $1,3,5,7(\mathrm{~A})$} & & Disk $1,3,5,7(\mathrm{~B})$ & Disk $1,3,5,7(\mathrm{C})$ \\
\hline $650^{\circ} \mathrm{C}\left(1200^{\circ} \mathrm{F}\right)$ & & & Disk $1,3,5,7(\mathrm{D})$ & Disk $1,3,5,7(\mathrm{~F})$ \\
\hline $677^{\circ} \mathrm{C}\left(1250^{\circ} \mathrm{F}\right)$ & & Disk $2,4,6,8(G)$ & Disk $2,4,6,8(\mathrm{H})$ & Disk $2,4,6,8(\mathrm{I})$ \\
\hline
\end{tabular}

Structural Evaluation

Modified electrolytic techniques for SEM observation were developed by J. Radavich ${ }^{[4]}$ and were used to reveal the following: 1) $\alpha-\mathrm{Cr}$ phase in relief, 2)preferential etching of $\alpha-\mathrm{Cr}$, or 3 )both the $\alpha-\mathrm{Cr}$ and $\delta-\mathrm{Ni}_{3} \mathrm{Nb}$ as separate particles. X-ray diffraction of extracted residues was used to confirm the presence of the $\alpha-\mathrm{Cr}$ phase. TEM thin foil observation has been conducted with selected area diffraction (SAD) to identify $\alpha-\mathrm{Cr}$ phase directly. A special designed electrolytic isolation and micro-chemical analyses have been used for weight fraction determination of $\alpha$-Cr phase ${ }^{[5]}$. Thermo-Calc software was used to evaluate the $\alpha-\mathrm{Cr}$ formation and to compare with micro-structural evaluation.

\section{Results and Discussions}

\section{Mechanical Properties}

Hardness. There was no significant difference in hardness among the groups of samples (as shown in Fig. 1) after exposure at $593^{\circ} \mathrm{C}, 650^{\circ} \mathrm{C}$ and $677^{\circ} \mathrm{C}$ till $2000 \mathrm{hrs}$. The mean hardness of the four group samples before the exposure was HRc45. After exposure at $593^{\circ} \mathrm{C}$ for $2000 \mathrm{hrs}$ the mean hardness of four groups increased to $48 \mathrm{HRc}$, because of the complementary precipitation of $\gamma^{\prime \prime}$ and $\gamma^{\prime}$ for age hardening. The mean hardness was 42 after exposure at $677^{\circ} \mathrm{C}$ for $2000 \mathrm{hrs}$. The largest decrease in mean hardness (from HRc45 to HRc40) appeared in samples exposed at $677^{\circ} \mathrm{C}$ for $2000 \mathrm{hrs}$, because of the softening effect developed by the strengthening phases $\left(\gamma^{\prime \prime}+\gamma^{\prime}\right)$ ) coagulation and $\gamma^{\prime \prime} \rightarrow \delta$ transformation.

$650^{\circ} \mathrm{C}$ Tensile Strength. These tensile strengths, YS and UTS, both have almost no noticeable reduction after $2000 \mathrm{hrs}$ exposures at $593^{\circ} \mathrm{C}$ and $650^{\circ} \mathrm{C}$ for 4 different processed disks as shown in Fig. $2 \mathrm{a}$. However, there is about $20 \%$ decrease in tensile strength after $677^{\circ} \mathrm{C}$ exposure for $2000 \mathrm{hrs}$ as shown in Fig. $2 \mathrm{~b}$. These results are in accordance with hardness tests 
(as shown in Fig.1) because of the softening effect developed at high temperature $\left(677^{\circ} \mathrm{C}\right)$ long time exposure (2000hrs).

$650^{\circ} \mathrm{C}$ Stress Rupture Lives. DA718 and Super II 718 (special fine grain processing +DA) characterize with highest hardness, $650^{\circ} \mathrm{C}$ tensile strengths and stress rupture lives (as shown In fig.1,2 and 3) among 4 different processed disks. However, a noticeable rupture time decrease was found after $649^{\circ} \mathrm{C}$ exposure for $2000 \mathrm{hrs}$ (see Fig.3a). A dramatic decrease of more than $80 \sim 90 \%$ in rupture times was found after the exposure at $677^{\circ} \mathrm{C}$ for $2000 \mathrm{hrs}$ (see Fig. 3b). All the times to rupture for DA718, Super II 718 Standard 718 and Super 1718 all decreased to very low levels, which were $34,22,15$ and 8 hrs respectively.

Impact Energy. The decrease in Charpy impact energy is noticeable for all 4 different processed disks even the hardness and tensile strengths both have almost no reduction after $650^{\circ} \mathrm{C}$ exposure till 2000hrs (see Fig.4a and 2a). A dramatic charpy impact energy decrease happened for all 4 different processed disks at $677^{\circ} \mathrm{C}$ exposure till 2000hrs (see Fig.4b). Among them the strength level of DA718 and Super II 718 dropped to lowest levels. For example, after $677^{\circ} \mathrm{C}$, $2000 \mathrm{hrs}$ exposure the impact energies of DA718 and Super II 718 were only $8.1 \mathrm{~J}$ and $10.8 \mathrm{~J}$ respectively and the impact energies of Standard and Super I 718 can keep 12.2J and 13.5J respectively.

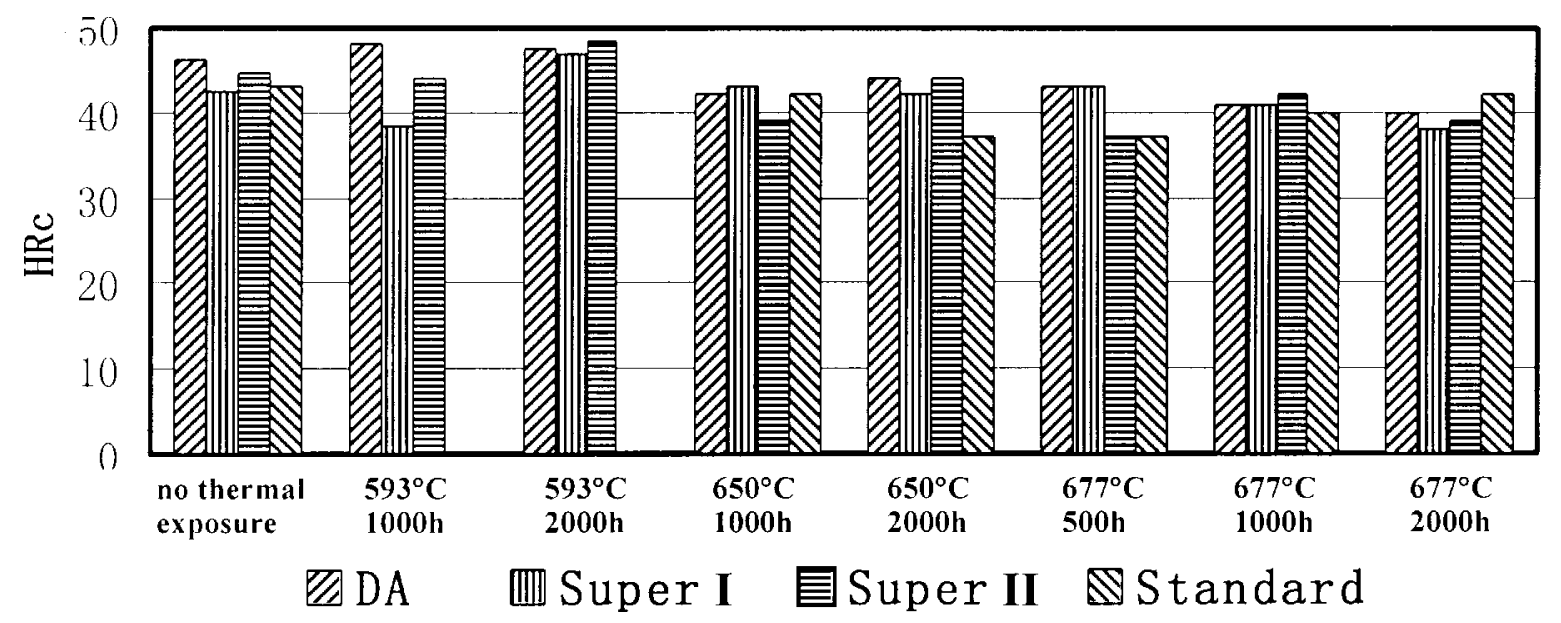

Figure 1: The hardness changes with thermal exposure time for 4 different processed 718 disks at temperature of $593^{\circ} \mathrm{C}, 649^{\circ} \mathrm{C}$ and $677^{\circ} \mathrm{C}$

\section{Structural and Phase analysis}

SEM structure observation on 4 different processed 718 disks after $649^{\circ} \mathrm{C}$ exposure for $2000 \mathrm{hrs}$ reveals the existence of $\alpha-\mathrm{Cr}$ (etched out black holes as shown in Fig.5). It is very clear that DA718 contains highest fraction of $\alpha-\mathrm{Cr}$ among them (in comparison Fig.5b with $5 \mathrm{a}, 5 \mathrm{c}$ and $5 \mathrm{~d})$. At higher temperature $\left(677^{\circ} \mathrm{C}\right)$ exposure, more $\alpha-\mathrm{Cr}$ formed, as an example certain amount of $\alpha-\mathrm{Cr}$ can be found in Standard 718 (compare Fig.6a with 5a). Fig.6b also show the increase of $\alpha-\mathrm{Cr}$ fraction in Super I 718 after $677^{\circ} \mathrm{C}$ exposure for $2000 \mathrm{hrs}$. The coagulation of main strengthening phase $\left(\gamma^{\prime \prime}\right.$ ) can be also detected by SEM observation ( in comparison with Fig.6 with Fig.5). 

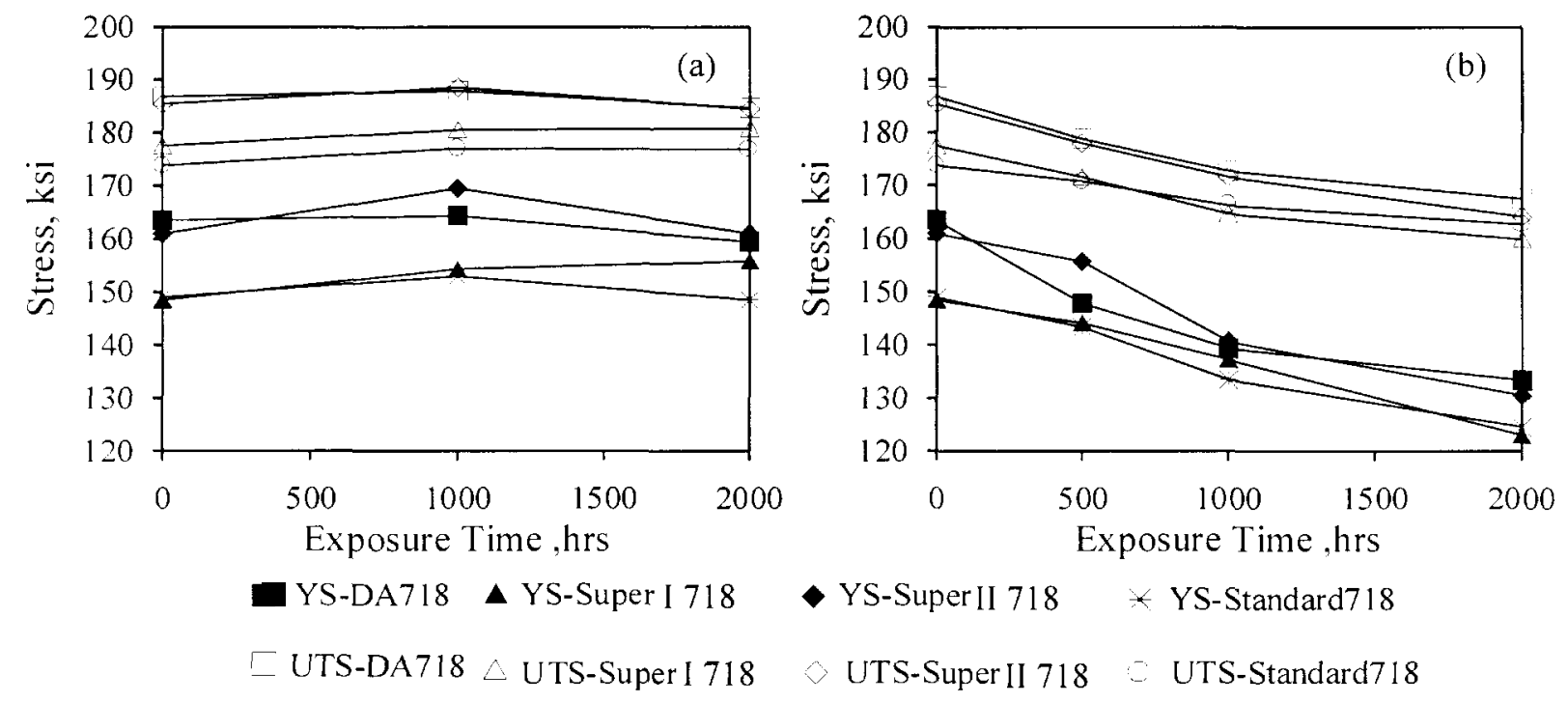

Figure2 The relationship of $650^{\circ} \mathrm{C}$ tensile strengths with thermal exposure time for 4 different processed 718 disks at temperatures (a) $649^{\circ} \mathrm{C}$, (b) $677^{\circ} \mathrm{C}$
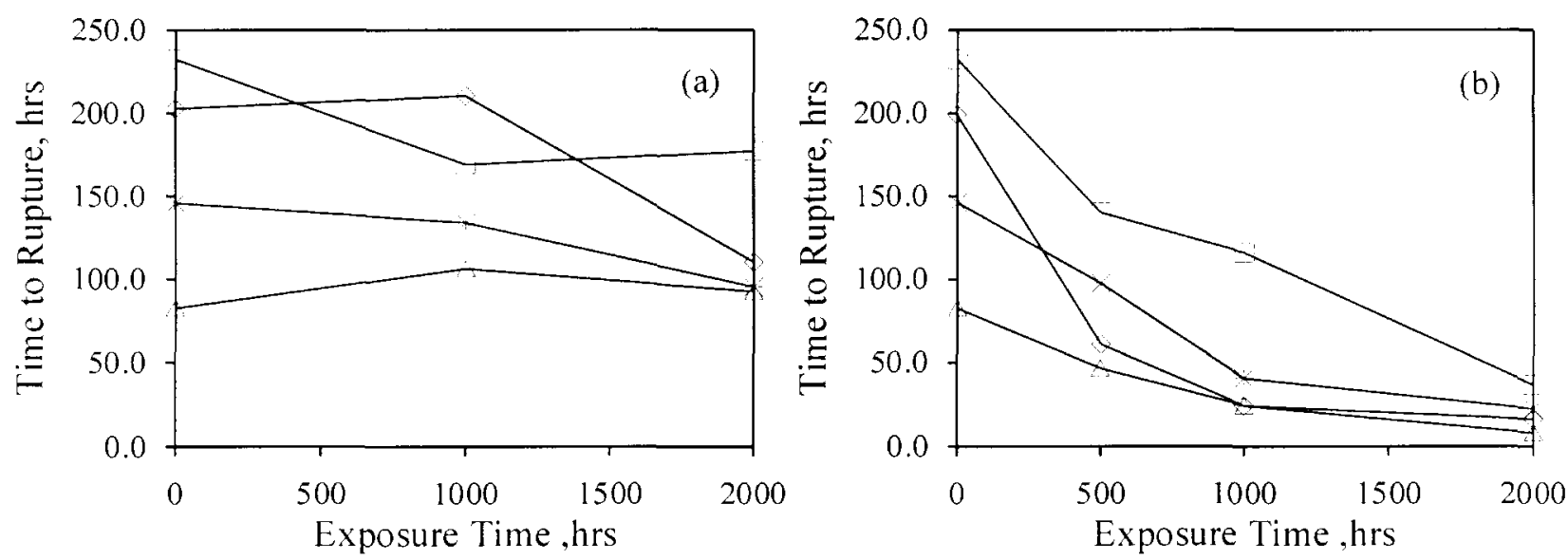

$\sqsubset$ DA718 $\triangle$ SuperI $718 \diamond$ SuperII $718 *$ Standard718

Figure. 3 The dependence of notched stress rupture $\left(650^{\circ} \mathrm{C}, 724 \mathrm{MPa}\right)$ lives on thermal exposure time for 4 different processed 718 disks at temperatures (a) $649^{\circ} \mathrm{C}$, (b) $677^{\circ} \mathrm{C}$
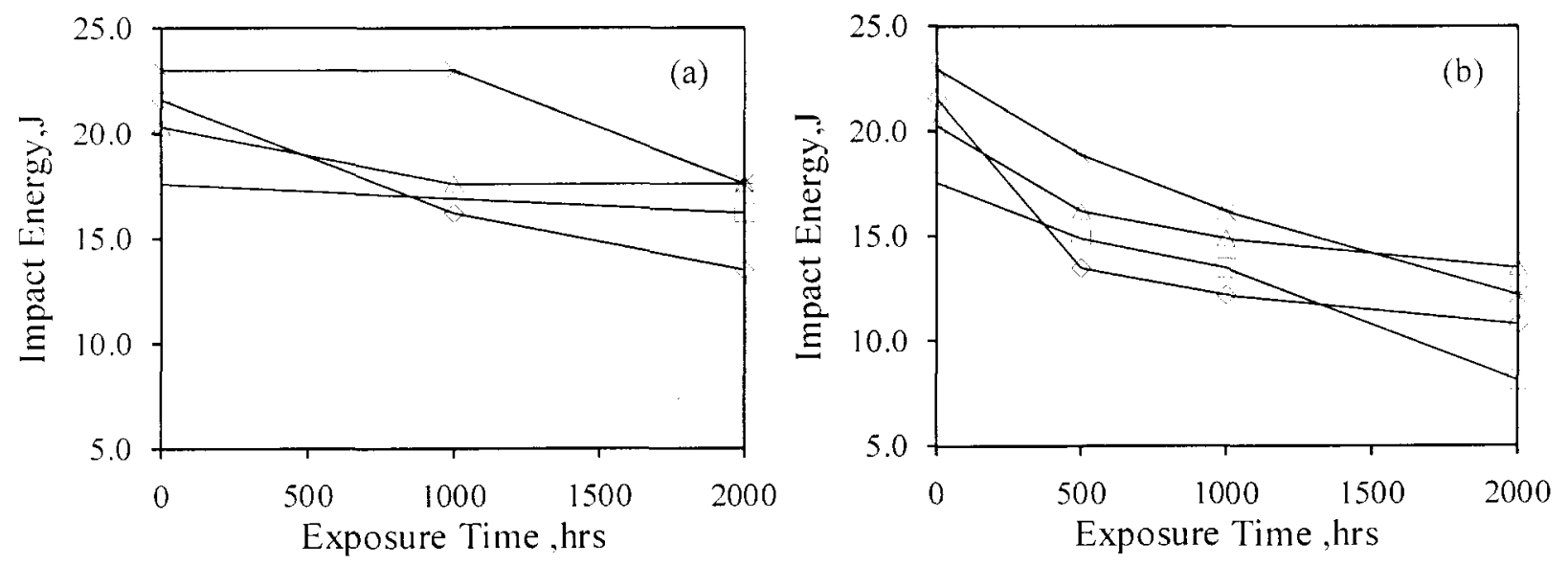

EDA718 $<$ Super $1718 \leftarrow$ SuperII $718 *$ Standard718

Figure. 4 The dependence of impact energy on thermal exposure time for 4 different processed 718 disks at temperatures (a) $649^{\circ} \mathrm{C}$, (b) $677^{\circ} \mathrm{C}$ 


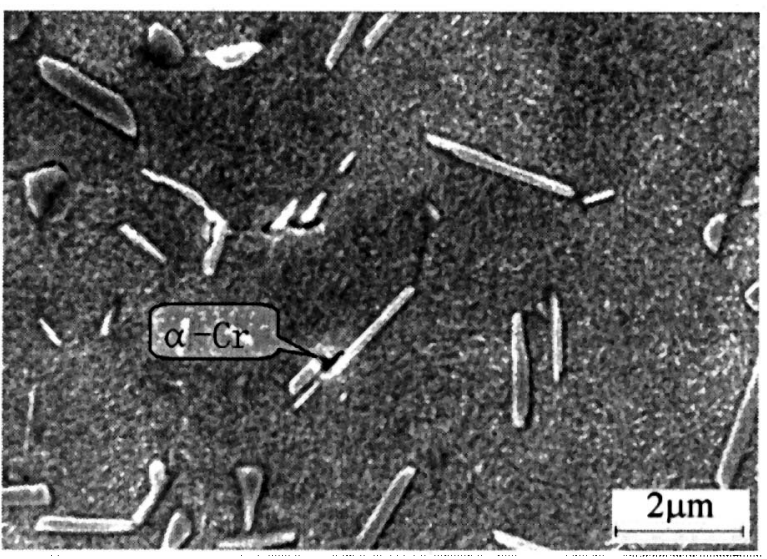

(a) Standard $718 / 649^{\circ} \mathrm{C} / 2000 \mathrm{hrs}$

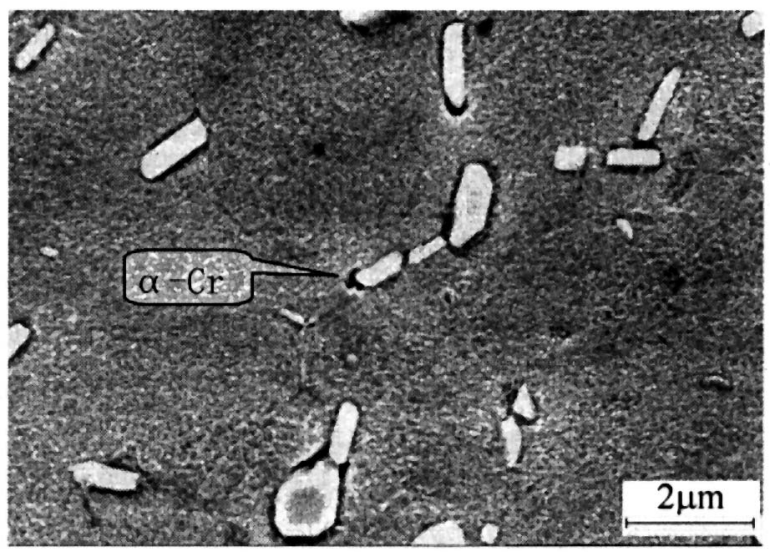

(c) Super I $718 / 649^{\circ} \mathrm{C} / 2000 \mathrm{hrs}$

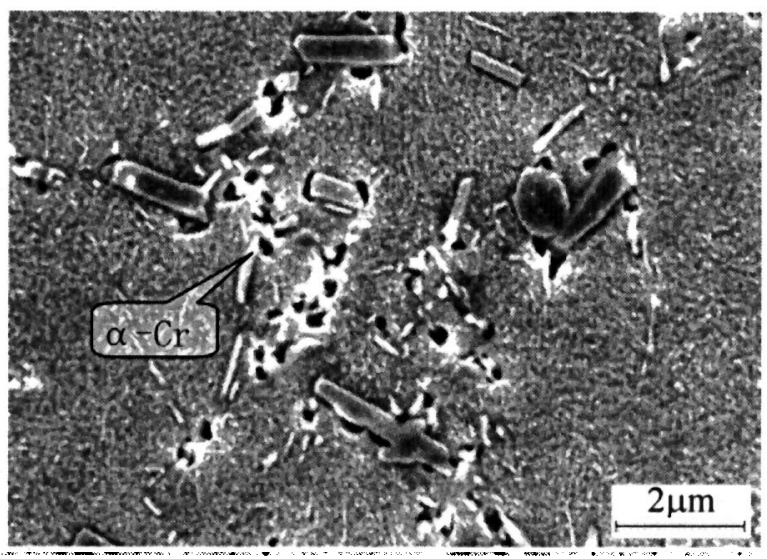

(b) DA $718 / 649^{\circ} \mathrm{C} / 2000 \mathrm{hrs}$

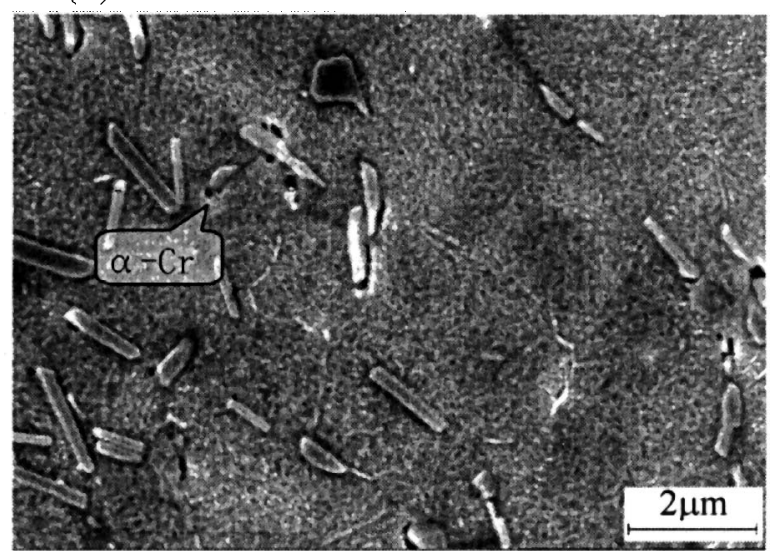

(d) Super II $718 / 649^{\circ} \mathrm{C} / 2000 \mathrm{hrs}$

Figure 5: SEM observation on 4 different processed 718 disks thermally exposed at $649^{\circ} \mathrm{C}\left(1200^{\circ} \mathrm{F}\right)$ for $2000 \mathrm{hrs}$

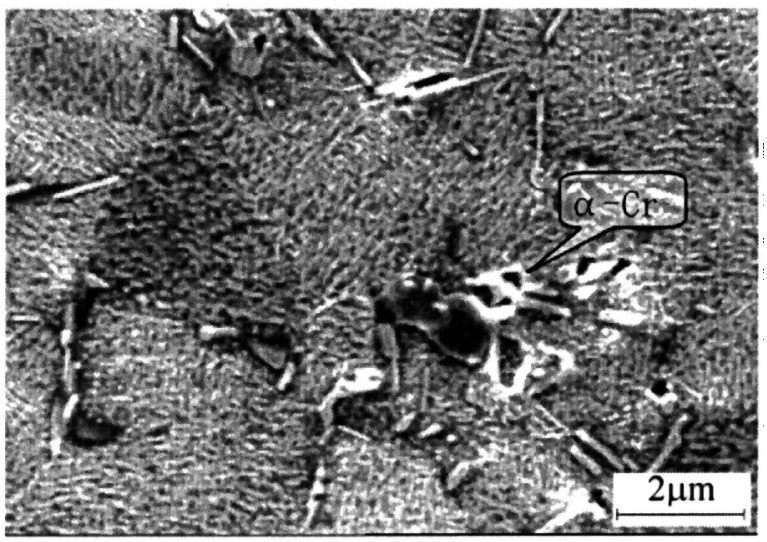

(a) Standard $718 / 677^{\circ} \mathrm{C} / 2000 \mathrm{hrs}$

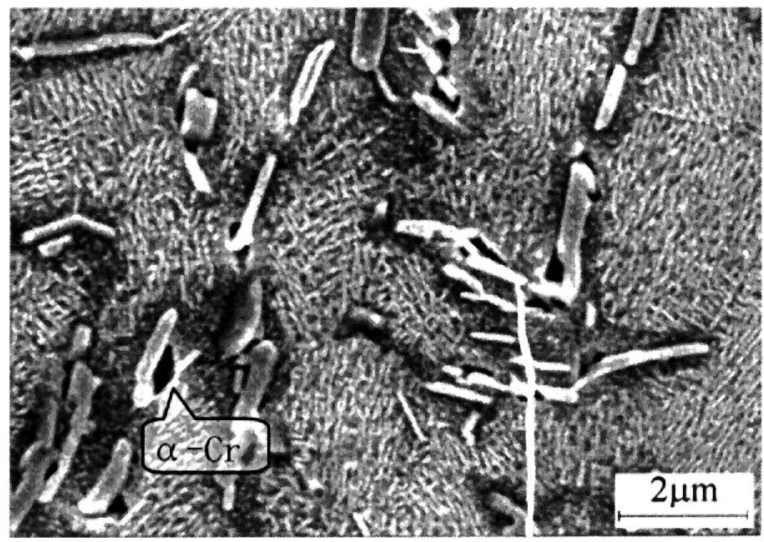

(b) Super I $718 / 677^{\circ} \mathrm{C} / 2000 \mathrm{hrs}$

Figure 6: SEM structure observation on standard 718 (a) and Super 1718 (b) disks thermally exposed at $677^{\circ} \mathrm{C}\left(1250^{\circ} \mathrm{F}\right)$ for $2000 \mathrm{hrs}$ 
X-ray diffraction on isolated residue confirms $\alpha-\mathrm{Cr}$ formation in 4 different processed 718 , Fig. 7 is an example of X-ray diffraction spectrum of Standard 718 after $677^{\circ} \mathrm{C}$ exposure for 2000 hrs. Fig. 8 shows the selective etching on $\alpha-\mathrm{Cr}$ (white particles) and EDS analysis directly on a "white particle", which characterizes with high content of $\mathrm{Cr}$. These results reveal $\alpha-\mathrm{Cr}$ identification in agreement with XRD diffraction. Further detail TEM observation shows $\alpha-\mathrm{Cr}$ often forms with $\delta-\mathrm{Ni}_{3} \mathrm{Nb}$ and $\mathrm{SAD}$ analysis confirms the co-existence of $\alpha-\mathrm{Cr}$ with $\delta-\mathrm{Ni}_{3} \mathrm{Nb}$ phase as shown in Fig.9. More TEM observations confirm the co-existence of $\alpha-\mathrm{Cr}$ with $\delta$ $\mathrm{Ni}_{3} \mathrm{Nb}$ phase as shown in Fig. 10. However, the detail mechanism of $\alpha-\mathrm{Cr}$ formation with $\delta$ $\mathrm{Ni}_{3} \mathrm{Nb}$ phase in Alloy 718 should be studied further.

Thermo-Calc results show that when the chromium content is higher than $16 \%, \alpha-\mathrm{Cr}$ (and also $\sigma$ phase) should form in Alloy 718 as shown in a Cr-IN718 pseudo-binary phase diagram 'see Fig.11) and the $\alpha$-Cr fraction is linearly increased with the chromium content as shown in Fig. 12.

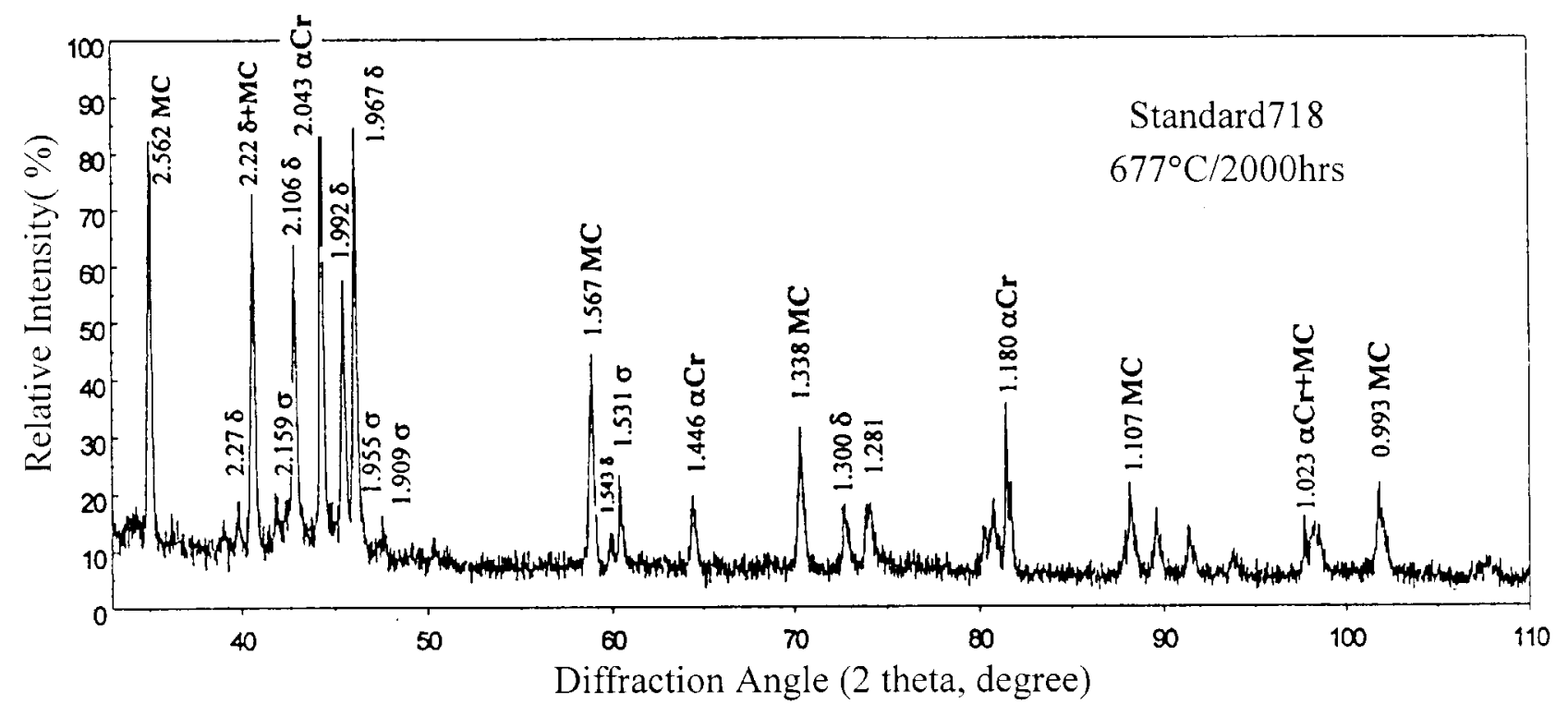

Figure 7: The X-ray diffraction spectrum of Standard 718 alloy thermally exposed at $677^{\circ} \mathrm{C}\left(1250^{\circ} \mathrm{F}\right)$ for $2000 \mathrm{hrs}$

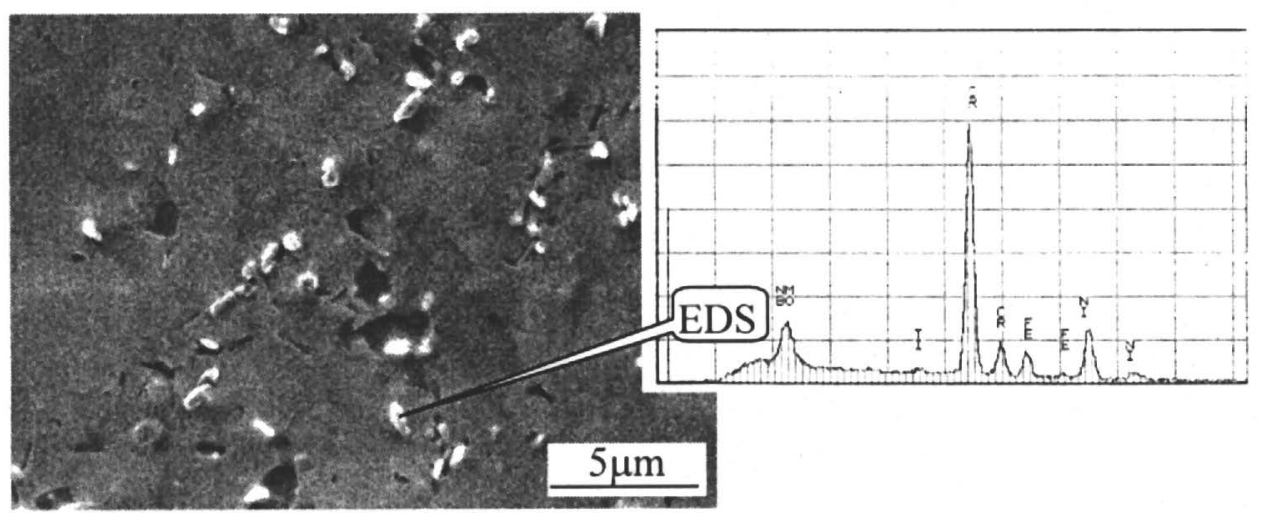

Figure 8: SEM morphology and EDS analysis of $\alpha-\mathrm{Cr}$ for Standard 718 alloy thermally exposed at $677^{\circ} \mathrm{C}\left(1250^{\circ} \mathrm{F}\right)$ for $2000 \mathrm{hrs}$ 

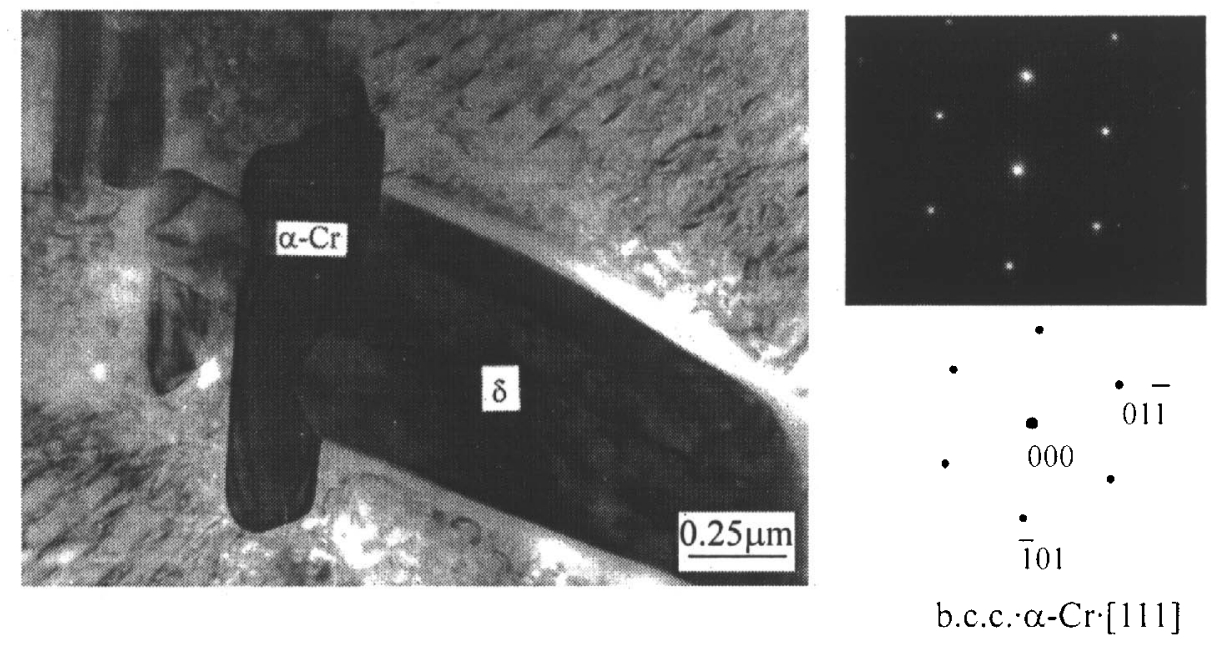

Figure 9: The morphology and selected area diffraction of $\alpha-\mathrm{Cr}$ phase in Standard 718 alloy thermally exposed at $677^{\circ} \mathrm{C}\left(1250^{\circ} \mathrm{F}\right)$ for $2000 \mathrm{hrs}$
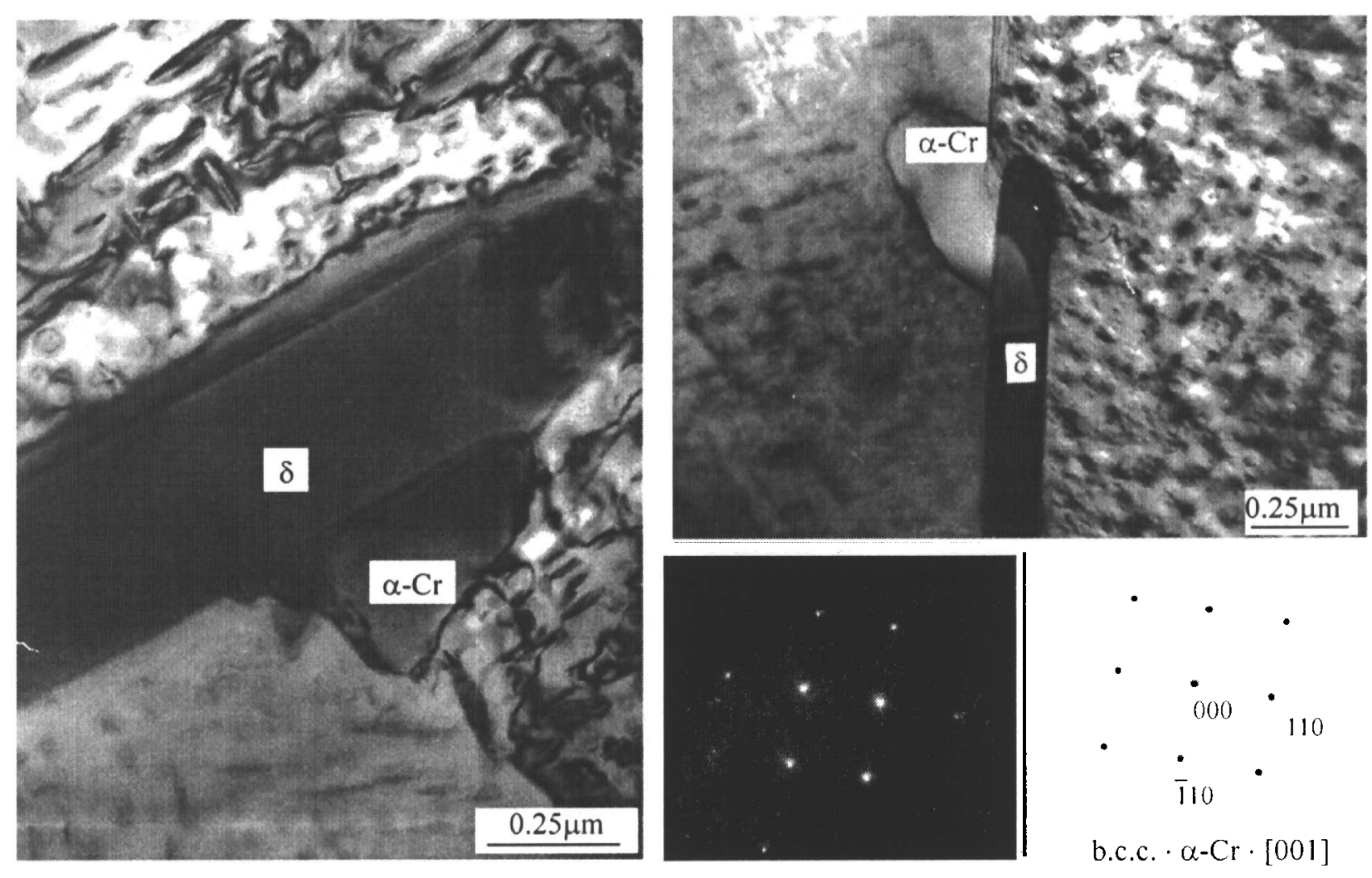

Figure 10: The co-existence of $\alpha-\mathrm{Cr}$ with $\delta-\mathrm{Ni}_{3} \mathrm{Nb}$ phase in Alloy 718 after $677^{\circ} \mathrm{C}\left(1250^{\circ} \mathrm{F}\right), 2000 \mathrm{hrs}$ exposure in (a) super I 718 disk and (b) Super II 718 disk 


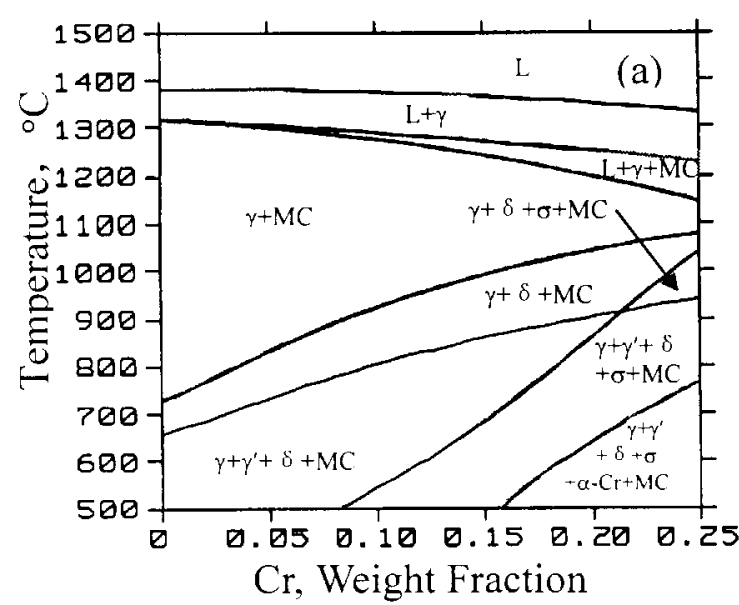

Figure 11: The Pseudo-Binary phase diagram of $\mathrm{Cr}-\mathrm{IN} 718$

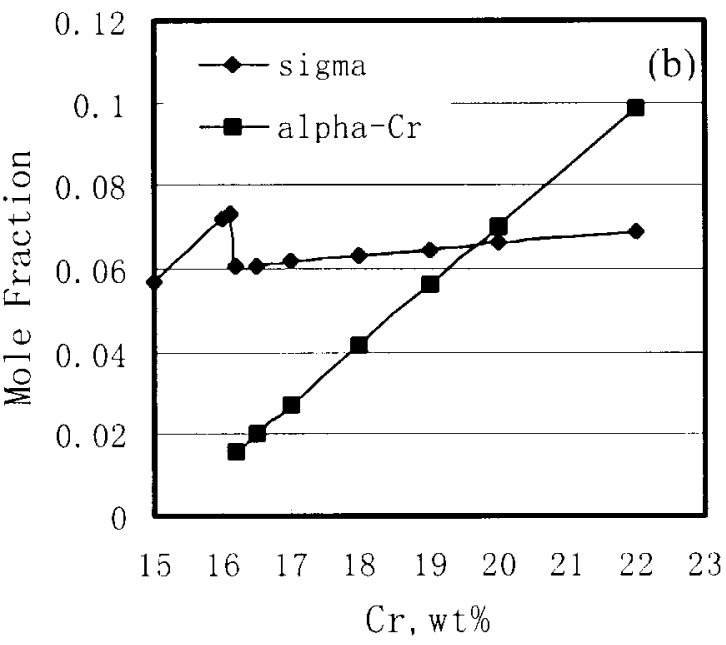

Figure 12: The mole fraction of $\alpha-\mathrm{Cr}$ and $\sigma$ phase vs $\mathrm{Cr}$ content in IN718

\section{Quantitative Determination of $\alpha-C r$ fraction}

The weight fraction of $\alpha-\mathrm{Cr}$ phase in 4 different processed 718 disks at $649^{\circ} \mathrm{C}$ and $677^{\circ} \mathrm{C}$ thermal exposure till $2000 \mathrm{hrs}$ was carefully determined by special designed electrolytic isolation and micro-chemical analyses ${ }^{[5]}$. Fig. 13 show the dependence of $\alpha-\mathrm{Cr}$ fraction on thermal exposure times at $649^{\circ} \mathrm{C}(\mathrm{a})$ and $677^{\circ} \mathrm{C}(\mathrm{b})$. It clearly shows that $\alpha-\mathrm{Cr}$ fraction keeps at very low levels for $649^{\circ} \mathrm{C}$ thermal exposure till $2000 \mathrm{hrs}$ and its fraction of Standard and Super I 718 are less than 0.018 and $0.042 \%$ wt. Super II 718 (fine grain forging $+\mathrm{DA}$ ) contains $0.135 \%$ wt $\alpha-\mathrm{Cr}$. However, DA718 contains highest level of $\alpha-\mathrm{Cr}$ fraction, which almost reaches $0.331 \% \mathrm{wt}$ because of the retained stress effect on promotion of $\alpha-\mathrm{Cr}$ formation due to direct aging after forging. Higher temperature $\left(677^{\circ} \mathrm{C}\right)$ exposure promotes $\alpha-\mathrm{Cr}$ formation because of high diffusion process in $\gamma$-matrix of Alloy 718. Fig.13b shows that $\alpha-\mathrm{Cr}$ fraction at $677^{\circ} \mathrm{C}$ exposure for $2000 \mathrm{hrs}$ can reach $0.190 \%, 0.364 \%, 0.419 \%$ and $0.618 \%$ for
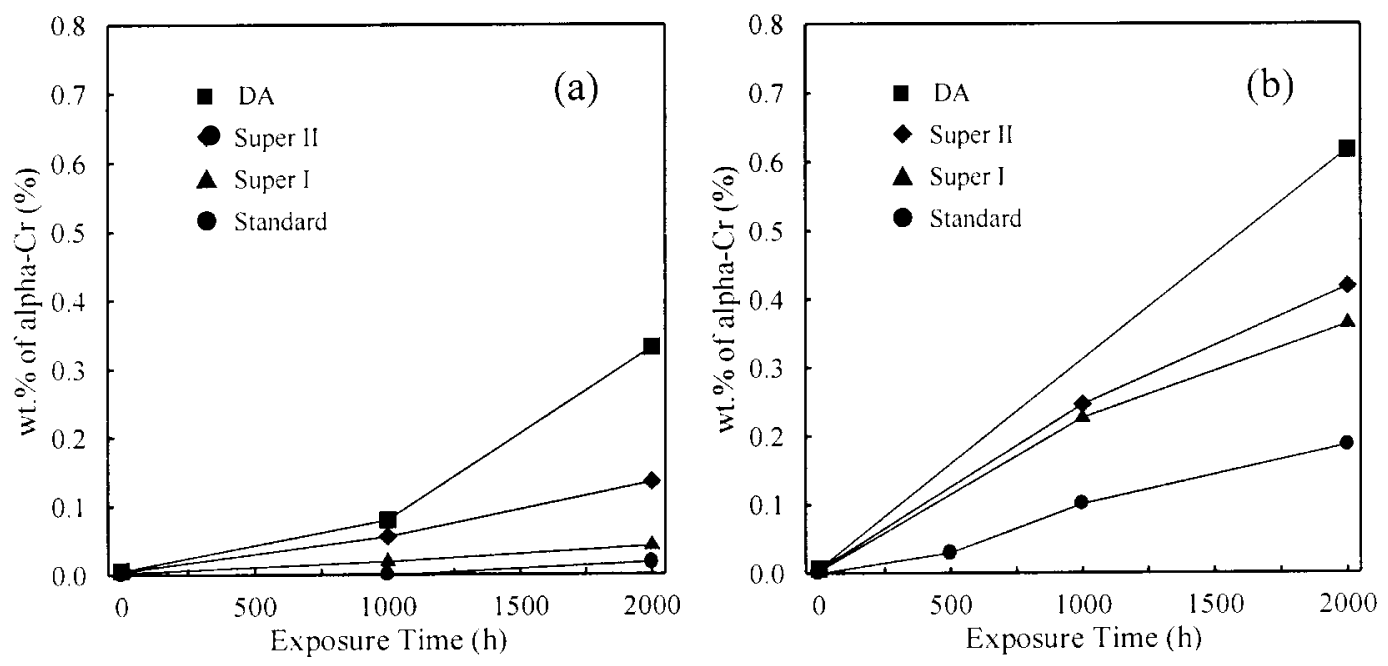

Fig.13: The dependence of $\alpha-\mathrm{Cr}$ on thermal exposure time for 4 different processed 718 disks 

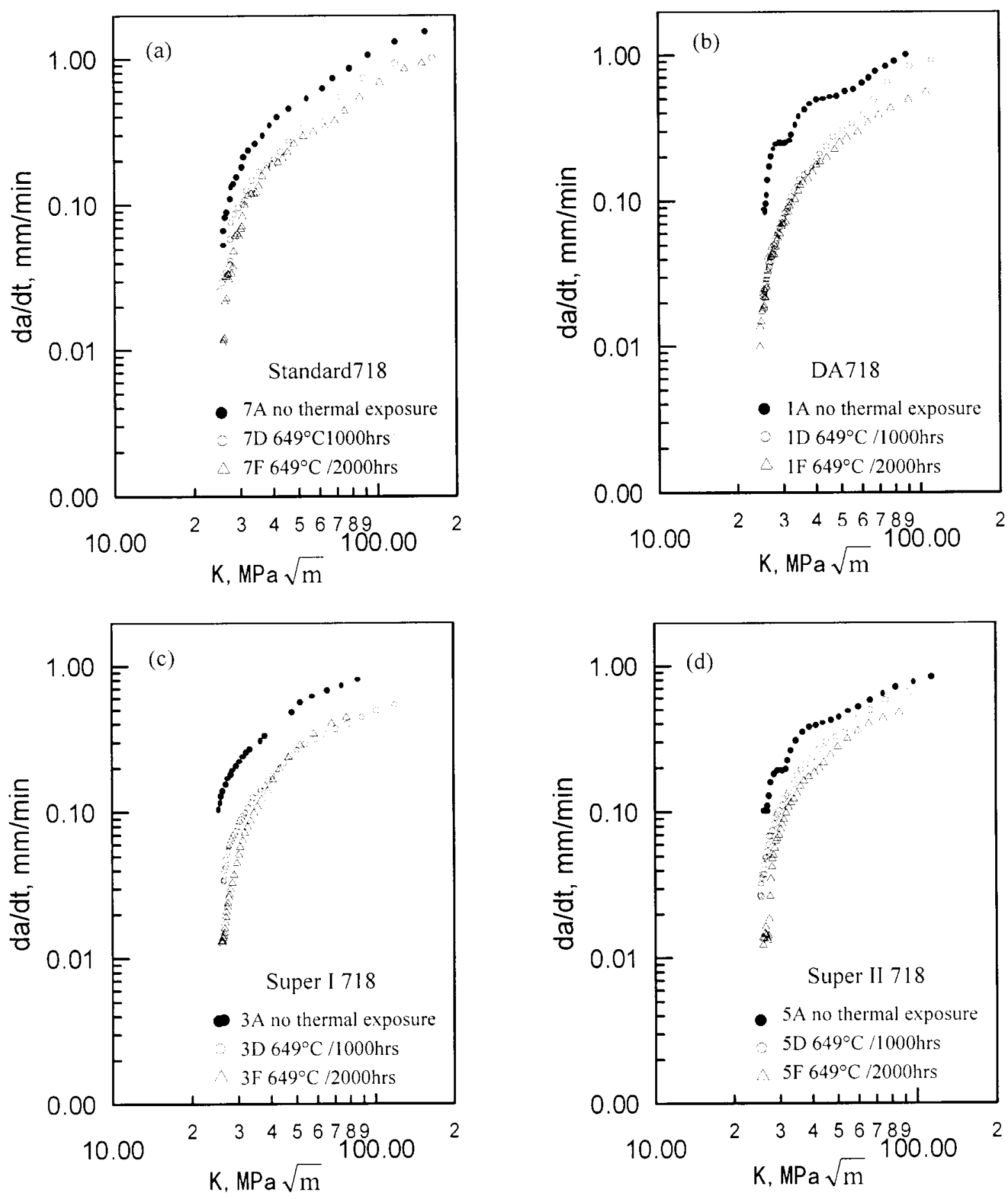

Figure 14: $650^{\circ} \mathrm{C}$ creep crack growth rate curves of 4 different processed 718 disks thermally exposed at $649^{\circ} \mathrm{C}\left(1200^{\circ} \mathrm{F}\right)$ till $2000 \mathrm{hrs}$,
(a) Standard 718
(b) DA718
(c) Super I 718
(d) Super II 718 

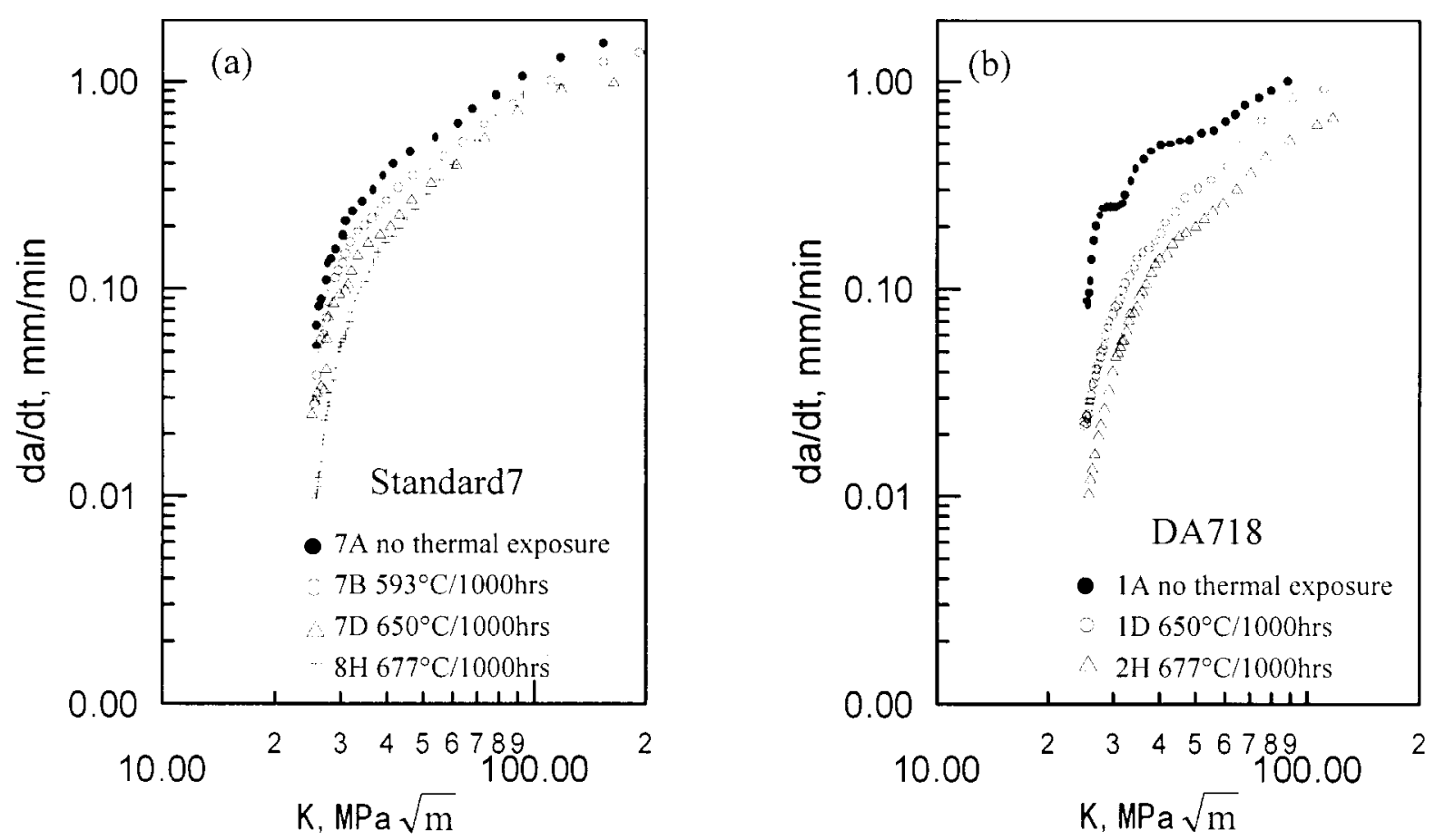

Fig.15: $650^{\circ} \mathrm{C}$ creep crack growth rate curves of Standard 718 (a) and DA718 (b) disks thermally exposed at different temperatures for $1000 \mathrm{hrs}$

Standard 718, Super I 718, Super II 718 and DA718 respectively. These quantitative results of $\alpha-\mathrm{Cr}$ fraction are in accordance with micro-structural analysis.

\section{$\underline{650^{\circ} \mathrm{C} \text { Creep Crack Propagation }}$}

Fig. 14 shows $650^{\circ} \mathrm{C}$ creep crack growth rate curves of 4 different processed 718 disks thermally exposed at $649^{\circ} \mathrm{C}$ till $2000 \mathrm{hrs}$. There are two main structure changes, which will effect the mechanical properties including creep crack propagation rate. Firstly, the coagulation of strengthening phases $\left(\gamma^{\prime \prime}+\gamma^{\prime}\right)$, which is a softening process and may reduce creep crack propagation rate. Secondly, $\alpha-\mathrm{Cr}$ formation which may cause embrittling effect to increase creep crack propagation rate. However, all creep crack growth rate curves of 4 different processed 718 disks decrease to lower levels with the thermal exposure times till 2000hrs at $677^{\circ} \mathrm{C}$. It seems to us a small amount of $\alpha$-Cr (less than $0.6 \% \mathrm{wt}$ ) will be not harmful for $650^{\circ} \mathrm{C}$ creep crack propagation resistance. Fig. 15 shows the creep crack growth rate curves of Standard 718 and DA 718 disks thermally exposed at $593^{\circ} \mathrm{C}, 649^{\circ} \mathrm{C}$ and $677^{\circ} \mathrm{C}$ for $1000 \mathrm{hrs}$. All creep crack growth rate curves drop to lower levels because of the intensive softening effect at higher temperatures. These experimental results indicate us that a small amount (less than $0.6 \% \mathrm{wt}$ ) of $\alpha-\mathrm{Cr}$ formation in 4 different processed 718 disks will not be harmful for $650^{\circ} \mathrm{C}$ creep crack propagation behavior, which is critical for disk application in aircraft and land-base gas turbines.

\section{Conclusions}

Structure stability study on Alloy 718 with 4 different forging/heat treatment process combinations, i.e., Standard 718, Super I 718, Super II 718 and DA718, has been conducted 
with long time thermal exposure at $593^{\circ} \mathrm{C}, 649^{\circ} \mathrm{C}$ and $677^{\circ} \mathrm{C}$ till $2000 \mathrm{hrs}$.

1. Alpha chromium ( $\alpha-\mathrm{Cr}$ ), a b.c.c. chromium enriched phase has been identified by XRD, SEM, TEM and SAD analyses. The existence of $\alpha-\mathrm{Cr}$ in Alloy 718 is also confirmed by Thermo-Calc method.

2. Alpha chromium ( $\alpha-\mathrm{Cr}$ ) precipitates are often in small globular particles $(\sim 0.3 \mu \mathrm{m})$ and form at the vicinity of $\delta-\mathrm{Ni}_{3} \mathrm{Nb}$ phase.

3. More $\alpha-\mathrm{Cr}$ particles will precipitate in Alloy 718 at higher exposure temperatures and longer times.

4. DA718 contains $\alpha$-Cr phase even without high temperature exposure. The fraction of $\alpha-\mathrm{Cr}$ grows as the exposure temperature and time increase.DA718 contains highest fraction of $\alpha-\mathrm{Cr}(0.62 \% \mathrm{wt})$ and Standard 718 contains lowest fraction of $\alpha-\mathrm{Cr}(0.19 \% \mathrm{wt})$ after $677^{\circ} \mathrm{C}, 2000 \mathrm{hrs}$ exposure among the 4 processed 718 disks, because retained stress promotes $\alpha-$ Cr precipitation.

5. The fraction of $\alpha-\mathrm{Cr}$ in 4 different processed Alloy 718 disks after high temperature long time exposure are not very high, only less than $1 \%$ wt. The small amount of $\alpha-\mathrm{Cr}$ in Alloy 718 does not has serious deleterious effect on $650^{\circ} \mathrm{C}$ creep crack propagation rate. However, the impact energy does decrease with thermal exposure time at $649^{\circ} \mathrm{C}$ and $677^{\circ} \mathrm{C}$.

6. A noticeable $650^{\circ} \mathrm{C}$ strengths drop, especially stress rupture time decrease was found after $649^{\circ} \mathrm{C}$ exposure for 2000 hrs. A dramatic decrease of more than $80 \sim 90 \%$ in rupture times of 4 different processed 718 disks was found after $677^{\circ} \mathrm{C}$ exposure for $2000 \mathrm{hrs}$.

\section{References}

[1] X. Xie et al., "Relationship of Microstructure with Mechanical Properties of Alloy 625 and 718 after Long Time Exposure", Long Term Stability of High Temperature Materials, Eds., G. E. Fuchs et al., TMS (1999) p135

[2] G.Shen et al., "The Effect of Processing on Stability of Alloy 718", Superalloys 2000, Eds., T. M. Pollock et al., TMS (2000) p445

[3] B. Lindsley et al., " $\alpha$-Cr Formation in Alloy 718 during Long Term Exposure: The Effect of Chemistry and Deformation", Long Term Stability of High Temperature Materials, Eds., G.E. Fuchs et al., TMS(1999) p123

[4] J.F. Radavich, Unpublished Research

[5] Gailian Wang, et al., "Micro-Chemical Phase Analysis of Inconel 718 after Longtime Thermal Exposure", to be published in 2001 